УДК 351.81

DOI https://doi.org/10.32836/2310-9653-2020-3.18

Г. П. Фердман, кандидат наук з державного управління, старший науковий співробітник, заступник начальника

з наукової роботи Науково-дослідного центру

Збройних сил України «Державний океанаріум»

Інституту Військово-Морських сил

Національного університету «Одеська морська академія»

\title{
ЗАБЕЗПЕЧЕННЯ БЕЗПЕКИ НА АВТОМОБІЛЬНОМУ ТРАНСПОРТІ: ДЕРЖАВНО-УПРАВЛІНСЬКИЙ АСПЕКТ
}

Визначено, щзо автомобільний транспорт - ие галузь транспорту, яка забезпечує задоволення потреб населення та суспільного виробництва в перевезеннях пасажирів та вантажів автомобільними транспортними засобами.

Забезпечення належного рівня управління безпекою автомобільного транспорту - одне з основних завдань сучасноі держави. За усвідомлення його значення для України необхідно приділяти більш значну увагу безпеиі автомобільного транспорту, яка натепер перебуває на недостатньому рівні.

Головним суб'єктом гарантування транспортної безпеки на автомобільному транспорті є Державна служба України з безпеки на транспорті (Укртрансбезпека), яка є центральним органом виконавчої влади, діяльність якого спрямовується $i$ координується Кабінетом Міністрів України через Міністра інфраструктури, і який реалізує державну політику з питань безпеки на наземному транспорті.

Відповідно до наказу Міністерства транспорту Украӥни від 12 листопада 2003 року № 877 було затверджено «Типове положення про Систему управління безпекою руху на автомобільному транспорті (на всіх рівнях міністерство - підприємство)», яке визначає порядок організації робіт із профілактичної діяльності щодо запобігання дорожньо-транспортним пригодам, основні завдання та функиії управління, органи, об 'єкти та суб'єкти управління, встановлює контроль за виконанням робіт.

Державна система управління безпекою руху на автомобільному транспорті охоплює иентральні органи виконавчої влади, урядові та територіальні органи державного управління, а також установи, організаціі, об 'єднання, підприємства всіх форм власності, які мають автомобільні транспортні засоби.

Управління безпекою руху на автомобільному транспорті здійснюється шляхом иілеспрямованого регулювання організаиійних, технічних, психофізіологічних чинників, щуо впливають на безпеку руху автомобільного транспорту. Органами управління є Міністерство інфраструктури України, Державний департамент автомобільного транспорту, автотранспортні управління, підприємства, що мають право ухвалювати управлінські рімення в межах своєї компетенції та стежити за виконанням ухвалених рімень.

Ключові слова: автомобільний транспорт, значення, особливість, аварійність, жертви, безпека, державне управління.

\section{G. P. Ferdman. Providing of safety on motor transport: state-administrative aspect}

It is defined that road transport is a branch of transport that provides satisfaction of the needs of the population and public production in transportation of passengers and cargoes by motor vehicles.

Motor transport is not only an economic but also an extraordinary socio-cultural phenomenon. Its development contributes to the elimination of ethnic and cultural differences between different regions, between urban and rural populations. Globally, it is a factor in world integration and the formation of a single civilizational space.

Ensuring an adequate level of road safety management is one of the main tasks of the modern state. Recognizing its importance for Ukraine, it is necessary to pay greater attention to road safety, which at present remains insufficient.

The main subject of ensuring road safety in road transport is the State Transport Service of Ukraine (Ukrtrans Security), which in turn is the central body of executive power, whose activity is directed and coordinated by the Cabinet of Ministers of Ukraine through the Minister of Infrastructure and who implements the state policy on issues safety on land transport.

In accordance with the Decree of the Ministry of Transport of Ukraine № 877 of 12.11.2003, the "Standard Provision on the Road Safety Management System for Road Transport (at all levels of the Ministry - the enterprise)" was approved, which defines the procedure for the organization of preventive activities to prevent accidents ( hereinafter-road accident), the main tasks and functions of management, bodies, objects and subjects of management, establishes control over the execution of works and includes the fulfillment of the following basic tasks: I safety vehicles, equipment, buildings, facilities, roads; ensuring transportation safety; provision (normalization) of psychophysiological factors of staff.

State Automobile Safety Management System transport covers the central executive, governmental and territorial bodies of state administration, as well as institutions, organizations, associations, enterprises of all forms of ownership which have motor vehicles.

Traffic safety management on road transport is carried out by purposeful regulation of organizational, technical, psychophysiological factors that affect road traffic safety. The governing bodies are the Ministry of Infrastructure of Ukraine, the State Department of Road Transport, motor transport departments, the Enterprises that have the right to make management decisions within their competence and to monitor the implementation of the decisions made.

Key words: motor transport, value, feature, accident rate, victims, safety, state administration.

(C) Г. П. Фердман, 2020 
Постановка проблеми. Автомобільний транспорт - це галузь транспорту, яка забезпечує задоволення потреб населення та суспільного виробництва в перевезеннях пасажирів та вантажів автомобільними транспортними засобами [1, ст. 1].

Автомобілізація - невід’ємний елемент прогресу суспільства. Роль автомобільного транспорту в сучасному світі важко переоцінити. Він має колосальне значення для задоволення соціально-економічних потреб людини, забезпечує динамічний розвиток промисловості, сільського господарства, торгівлі, медицини та багатьох інших сфер суспільного життя. Без нього неможливі перевезення, відпочинок і спілкування людей, неможлива стабільна робота органів влади, соціальних інститутів, підприємств, установ, організацій [2, с. 78].

Автотранспорт - це не лише економічний, а й непересічний соціокультурний феномен. Його розвиток сприяє усуненню етнічних і культурних відмінностей між різними регіонами, між міським та сільським населенням. Глобально він виступає чинником світової інтеграції та формування єдиного цивілізаційного простору.

Згідно з офіційною статистикою Держстату, за 2019 р. послугами пасажирського транспорту скористалося 4 262,4 млн пасажирів. Автомобільним транспортом перевезено 1 804,9 млн пасажирів (94,7\% до 2018 р.); міським електричним транспортом - 1 573,2 млн пасажирів (93,7\% до 2018 р.), зокрема: трамваєм - 627,5 млн пасажирів; тролейбусом - 945,7 млн пасажирів. Загальна кількість пасажирів, перевезених автомобільним та міським електричним транспортом (автобус, трамвай, тролейбус), становить 3 378,1 млн осіб, або 79,3\% від загальної кількості перевезених пасажирів усіма видами транспорту [3, с. 1].

Автотранспортні підприємства - це важлива сфера, оскільки вони мають значний вплив на покращення безпеки на дорогах. Варто зазначити, що розроблено різноманіття стандартів управління організацій ними, технологічними і транспортними системами, проте переважно в морській, залізничній і повітряній галузях. Однією з головних цілей управління автомобільним транспортом є прагнення значно зменшити кількість дорожньо-транспортних пригод (далі - ДТП) («нульова смертність»), зокрема кількість важких аварій.

Проблеми транспортної безпеки за останні роки стали ще гостріше, оскільки транспорт фактично перетворився на одну з найризикованіших сфер життєдіяльності, у якій, на жаль, регулярно гинуть люди. Згідно зі статистичними даними, за 2019 р. на автошляхах України сталося 2829 ДТП за участю автомобільного транспорту, які надають послуги з перевезення пасажирів та небезпечних вантажів автомобільним транспортом, у яких 184 особи загинули та 1588 зазнали травм. Із зазначеної кількості аварій із вини водіїв ліцензованого автомобільного транспорту за вказаний період сталось 1507 дорожньо-транспортних пригод, у яких 63 особи загинули, а 744 отримали травми різного ступеня тяжкості. Також за 2019 р. сталося 14 пожеж на автомобільному транспорті загального користування без загиблих та травмованих. На міському електричному транспорті за 2019 р. сталося 683 дорожньо-транспортні пригоди за участю міського електричного транспорту, у яких 9 осіб загинули та 194 особи отримали травми. 3 вини водіїв міського електричного транспорту за вказаний період сталось 249 дорожньо-транспортних пригод, у яких 2 особи загинули, а 55 осіб отримали травми різного ступеня тяжкості. Також за 2019 р. сталося 4 пожежі на рухомому складі міського електричного транспорту без загиблих та травмованих [4, с. 12-13].

Водночас автомобілізація супроводжується деякими негативними процесами. Стрімке збільшення парку транспортних засобів, безперервна інтенсифікація дорожнього руху, негативний вплив людського чинника - усі ці фактори зумовлюють критично високий, порівняно з іншими техногенними системами, рівень аварійності.

Величезна кількість дорожньо-транспортних пригод стали наслідком відставання дорожнього будівництва від темпів автомобілізації, тотального занепаду дорожнього господарства, конструктивних недоліків транспортних засобів, слабкої водійської підготовки, зниження правосвідомості учасників дорожнього руху, архаїзму вітчизняної системи убезпечення дорожнього руху та багатьох інших прогресуючих проблем. Ці проблеми виникли не сьогодні і не вчора. Вони накопичувалися роками в умовах безальтернативності директивних схем управління, невизначеності меж компетенції (читай - сфер відповідальності) владних суб' єктів, браку реального інтересу до їх вирішення [2, с. 78-79].

Отже, забезпечення належного рівня управління безпекою автомобільного транспорту є одним 3 основних завдань сучасної держави. Усвідомлюючи його значення для України, необхідно приділяти більше уваги безпеці автомобільного транспорту, яка натепер залишається на недостатньому рівні.

Аналіз останніх досліджень і публікацій. Проблема гарантування безпеки на автомобільному транспорті постійно перебуває в полі зору різних науковців, зокрема, можна виділити праці: С.М. Гусарова, О.В. Кузьменко, Х.П. Ярмакі, М.М. Долгополова, О.Ю. Салманова, С.Г. Братель, Ю.А. Тихомирова, Е.В. Талапіна, С.І. Азарова, Т.В. Блудової, С.С. Богатчук, О.С. Бодрука, В.І. Гурковського, Б.Ю. Депутата, О.М. Дуднікова, В.К. Конаха, В.Р. Котковського, П.П. Луцюка, Ю.В. Марченка, В.П. Матейчика, В.А. Мисливого, О.А. Палія, В.Й. Развадовського, С.В. Руденка, Г.І. Рудька, Г.П. Ситника, О.Й. Соколова, В.І. Творонович, І.В. Толокньова, О.В. Філіпенка, I.К. Шаши, В.М. Шмандія й інших вітчизняних і закордонних учених. Водночас окремі питання в цій сфері потребують подальшого обговорення та вдосконалення.

Мета статті полягає в короткому висвітленні особливої ролі автомобільного транспорту в єдиній транспортній системі України, його особливостей, з деякими статистичними даними перевезень і аварійності за 2019 р., 
актуальності проблеми управління безпекою на автомобільному транспорті й організаційно-правових основ державного управління безпекою на автотранспорті України, з відповідними висновками.

Виклад основного матеріалу. Головним суб'єктом гарантування транспортної безпеки на автомобільному транспорті є Державна служба України з безпеки на транспорті (далі - Укртрансбезпека) - центральний орган виконавчої влади, діяльність якого спрямовується і координується Кабінетом Міністрів України через Міністра інфраструктури, і який реалізує державну політику з питань безпеки на наземному транспорті.

Основні завдання Укртрансбезпеки стосовно автомобільного транспорту такі:

1) реалізація державної політики з питань безпеки на автомобільному транспорті;

2) внесення на розгляд Міністра інфраструктури пропозицій щодо забезпечення формування державної політики з питань безпеки на автомобільному транспорті;

3) здійснення державного нагляду (контролю) за безпекою на автомобільному транспорті;

4) надання в передбачених законом випадках адміністративних послуг у сфері автомобільного транспорту [5, ст. 4].

Варто зазначити, що Укртрансбезпека під час виконання покладених на неї завдань взаємодіє з іншими державними органами, допоміжними органами і службами, утвореними Президентом України, тимчасовими консультативними, дорадчими й іншими допоміжними органами, утвореними Кабінетом Міністрів України, органами місцевого самоврядування, об’єднаннями громадян, громадськими спілками, профспілками й організаціями роботодавців, відповідними органами іноземних держав і міжнародних організацій, а також підприємствами, установами й організаціями.

Відповідно до наказу Міністерства транспорту України від 12 листопада 2003 р. № 877, затверджено «Типове положення про Систему управління безпекою руху на автомобільному транспорті (на всіх рівнях міністерство - підприємство)», яке визначає порядок організації робіт із профілактичної діяльності щодо запобігання ДТП, основні завдання та функції управління, органи, об’єкти та суб'єкти управління, встановлює контроль за виконанням робіт.

Згідно з вищезазначеним Положенням, управління безпекою руху повинно включати виконання таких основних завдань: гарантування безпеки транспортних засобів, устаткування, споруд, об'єктів, автомобільних доріг; убезпечення перевезень; забезпечення (нормалізація) психофізіологічних чинників персоналу.

Державна система управління безпекою руху на автомобільному транспорті охоплює центральні органи виконавчої влади, урядові та територіальні органи державного управління, а також установи, організації, об'єднання, підприємства всіх форм власності, які мають автомобільні транспортні засоби (далі - Підприємства).

Управління безпекою руху на автомобільному транспорті здійснюється шляхом цілеспрямованого регулювання організаційних, технічних, психофізіологічних чинників, що впливають на безпеку руху автомобільного транспорту. Органами управління є Міністерство інфраструктури України, Державний департамент автомобільного транспорту, автотранспортні управління, Підприємства, що мають право ухвалювати управлінські рішення в межах своєї компетенції та стежити за виконанням ухвалених рішень. Організаційно-функціональну схема управління безпекою руху на автомобільному транспорті України наведено на рис. 1.

До функцій управління безпекою руху автотранспорту належить організація роботи, яка передбачає:

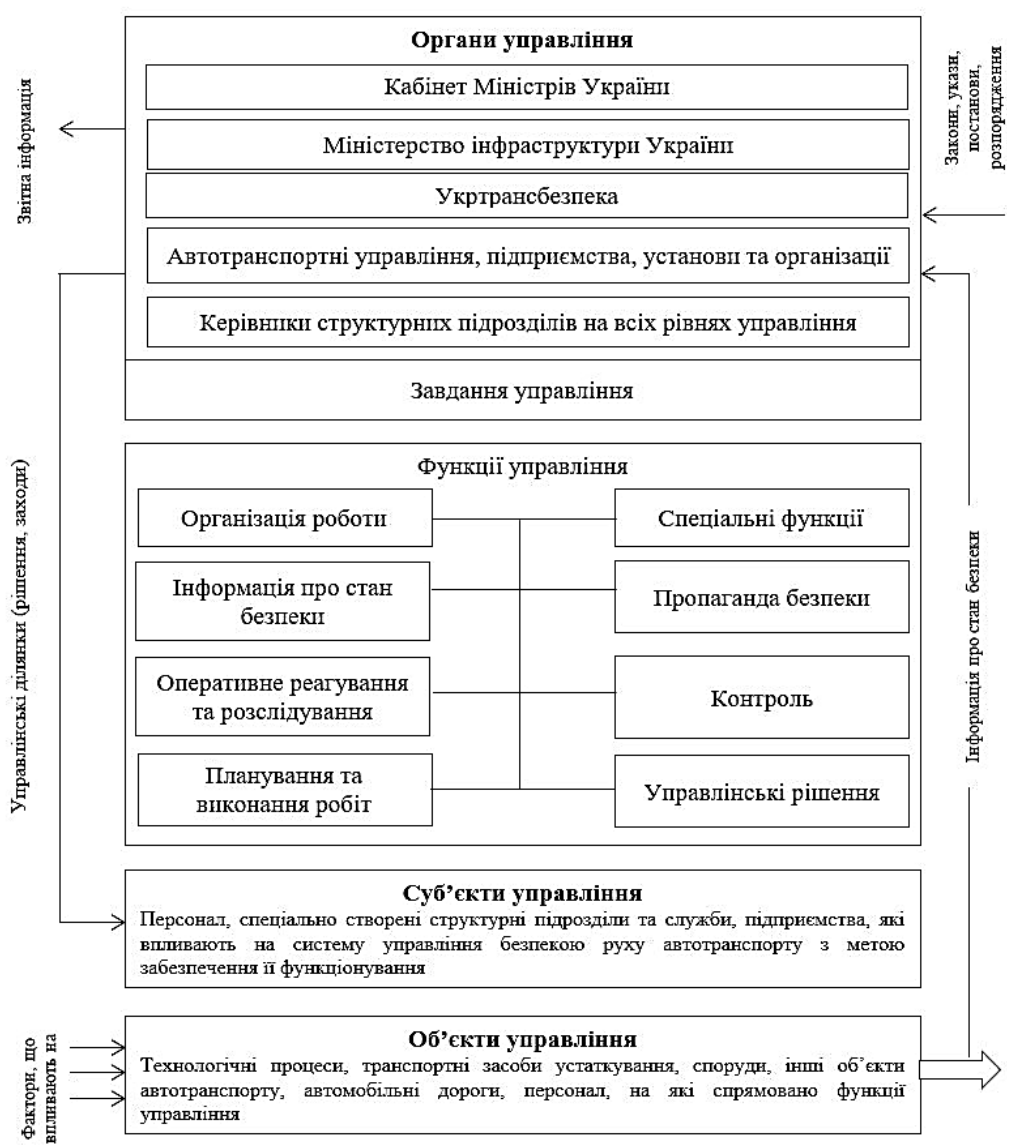

Рис. 1. Організаційно-функціональна схема управління безпекою руху на автомобільному транспорті України 
- завдання управління безпекою руху на автомобільному транспорті;

- визначення органів управління безпекою руху;

- встановлення функціональних обов'язків структурних підрозділів та посадових осіб із питань безпеки руху;

- регламентацію діяльності керівників та посадових осіб;

- нормативне забезпечення управління безпекою руху [6, ст. 4.3].

Висновки 3 дослідження і перспективи подальших розвідок у цьому напрямі. Отже, з урахуванням вищенаведеного можна дійти таких висновків:

1. Гарантування належного рівня транспортної безпеки України є одним з основних завдань сучасної держави, iï стан порівняно з розвиненими країнами світу незадовільний, тому їй поки що приділяється недостатня увага.

2. Державне управління у сфері безпеки автомобільного транспорту здійснює Державна служба України з безпеки на транспорті (Укртрансбезпека), яка є центральним органом виконавчої влади, діяльність якого спрямовується і координується Кабінетом Міністрів України через Міністра інфраструктури, і який реалізує державну політику з питань безпеки на наземному транспорті.

3. Гарантуванню безпеки автомобільного транспорту забезпечує слугують відповідні керівні документи, сили та засоби.

4. Водночас відсутнє загальне керівництво транспортною безпекою України та взаємодії автомобільного транспорту з іншими видами транспорту у сфері транспортної безпеки, яка була б оформлена відповідними документами.

Перспективами подальших розвідок у даному напрямі вважаємо дослідження переходу на європейські стандарти транспортної безпеки на всіх видах транспорту в Україні.

\section{Список використаних джерел:}

1. Про автомобільний транспорт : Закон України (зі змінами) від 23 лютого 2006 р. № 3492-IV. Bidомості Верховної Ради України. 2006. № 32. Ст. 273. URL: https://zakon.rada.gov.ua/laws/show/2344-14 (дата звернення: 19.04.2020).

2. Гуржій Т.О. Актуальні проблеми державного контролю у сфері безпеки дорожнього руху. Aдміністративне право і процес : науково-практичний журнал. 2012. № 1 (1). URL: http://www.library.univ.kiev.ua/ukr/host/ viking/db/ftp/univ/apip/apip_2012_01.pdf (дата звернення: 19.04.2020).

3. Загальна інформація про галузь (Автомобільний та міський транспорт). URL: https://mtu.gov.ua/content/ zagalna-informaciya-pro-galuz.html (дата звернення: 19.04.2020).

4. Публічний звіт Голови Державної служби України з безпеки на транспорті Олександра Погорілого за 2019 p. URL: https://www.kmu.gov.ua/storage/app/sites/1/17-civik-2018/zvit_2019/zvit-2019-ukrtransbezpeka.pdf (дата звернення: 19.04.2020).

5. Про затвердження Положення про Державну службу України з безпеки на транспорті : постанова Кабінету Міністрів України від 11 лютого 2015 р. № 103 (зі змінами). URL: https://zakon.rada.gov.ua/laws/show/103-2015\% $0 \%$ BF (дата звернення: 19.04.2020).

6. Типове положення про Систему управління безпекою руху на автомобільному транспорті (на всіх рівнях міністерство - підприємство) : наказ Міністерства транспорту України від 12 листопада 2003 p. № 877. URL: https://zakon.rada.gov.ua/rada/show/v0877361-03 (дата звернення: 19.04.2020).

\section{References:}

1. Zakon Ukrainy "Pro avtomobilnyi transport" (iz zminamy) vid 23.02.2006 № 3492-IV, VVR, 2006, № 32, st. 273 URL: https://zakon.rada.gov.ua/laws/show/2344-14 (data zvernennia 19.04.20).

2. Hurzhii T.O. "Aktualni problemy derzhavnoho kontroliu u sferi bezpeky dorozhnoho rukhu" naukovo-praktychnyi zhurnal Administratyvne pravo i protses № 1 (1) / 2012 URL: http://www.library.univ.kiev.ua/ukr/host/viking/db/ftp/ univ/apip/apip_2012_01.pdf (data zvernennia 19.04.20).

3. Zahalna informatsiia pro haluz (Avtomobilnyi ta miskyi transport) URL: https://mtu.gov.ua/content/zagalnainformaciya-pro-galuz.html (data zvernennia 19.04.20).

4. Publichnyi zvit Holovy Derzhavnoi sluzhby Ukrainy z bezpeky na transporti Oleksandra Pohoriloho za 2019 rik URL: https://www.kmu.gov.ua/storage/app/sites/1/17-civik-2018/zvit_2019/zvit-2019-ukrtransbezpeka.pdf (data zvernennia 19.04.20).

5. Postanova Kabinetu Ministriv Ukrainy vid 11 liutoho 2015 r. № 103 (iz zminamy) "Pro zatverdzhennia Polozhennia pro Derzhavnu sluzhbu Ukrainy z bezpeky na transporti” URL: https://zakon.rada.gov.ua/laws/show/ 103-2015-\%D0\%BF (data zvernennia 19.04.20).

6. "Typove polozhennia pro Systemu upravlinnia bezpekoiu rukhu na avtomobilnomu transporti (na vsikh rivniakh - ministerstvo - pidpryiemstvo)" Nakaz Ministerstva transportu Ukrainy vid 12.11.2003 № 877 URL: https://zakon.rada.gov.ua/rada/show/v0877361-03 (data zvernennia 19.04.20). 